\title{
FINAL
}

TIME PRESENT AND TIME PAST: RIVALRY AND THE DURATION OF INTERSTATE WARS, 1846-1985

Stephen B. Long 


\section{ABSTRACT \\ TIME PRESENT AND TIME PAST: RIVALRY AND THE DURATION OF INTERSTATE WARS, 1846-1985}

This paper sits at the intersection of the rivalry, war duration, and bargaining literatures, suggesting that histories of armed conflict between states increase war duration through their effects on the selectorate and the wartime bargaining process. I argue that the historical relationship between two states plays an integral role in the duration of future conflict. Specifically, historical conflict between states intensifies the preference of national selectorates for military victory and narrows the range of negotiated settlements that leaders might pursue while still maintaining domestic political support.

I employ Bennett and Stam's (1996) ex ante data set and Crescenzi and Enterline's (2001) International Interaction Score to provide an empirical test of the generalizability of appropriately coded historical interaction to the topic of war duration. Contradicting earlier studies, the results of this analysis show that a properly operationalized measure of rivalry has significant and positive effects on war duration.

Key Words: rivalry, duration, war

AUTHOR'S NOTE: This is a pre-publication draft of this paper and is not intended for citation. Please see the complete version as published in International Interactions 29:3 (July-September), pp. 215-236. For their many helpful comments and suggestions, I thank Stephen Biddle, Mark Crescenzi, Thomas Oatley, and the anonymous reviewers. Earlier versions of this paper were presented at the 2001 annual meeting of the American Political Science Association, San Francisco, and the 2001 annual meeting of the Peace Science Society, Atlanta. 


\section{INTRODUCTION}

Time present and time past

Are perhaps present in time future,

And time future contained in time past.

T.S. Eliot

Why do some interstate wars seem to end almost as soon as they begin, while others continue unchecked for years at the cost of thousands of human lives? Are existing explanations focusing on realpolitik, strategic, and regime type variables sufficient to answer this understudied question, or can we improve upon those explanations by considering the influence of historical rivalries between states on war duration? This paper will attempt to answer these questions through the incorporation of a new and innovative measure of rivalry into an existing model of war duration. The endeavor will yield insights that will not only reverse prior findings on the role of rivalry but will be beneficial to the literature covering two major topics of interest in international relations as a discipline.

A large and diverse literature on the empirical importance of rivalries exists (i.e. Goertz and Diehl 1992, 1993, 1995; Geller 1993; Hensel 2001) and a number of qualitative and quantitative studies provide suggestions about the factors that influence war duration (i.e. Bennett and Stam 1996; Vuchinich and Teachman 1993; Goemans 2000), but the two fields have as of yet been on different tracks. Previous work on rivalries has focused primarily on separating enduring rivalries as an empirical phenomenon from other types of interstate conflict, while existing work on interstate war duration either ignores or inadequately operationalizes rivalry, misevaluating its substantive importance. 
The goal of this paper is to create and test a model of war duration that expects the rational calculations of actors to be influenced not only by realpolitik inputs such as balance of forces, but also domestic pressure related to historical interaction with the opponent, as manifested in a narrowed range of acceptable negotiated settlements. This paper will argue that the presence and magnitude of a rivalry increases the intensity of the selectorate's preference for military victory. ${ }^{1}$ As a result, the selectorate limits the ability of the decision-maker to accept negotiated settlements that include compromises, as these outcomes may be viewed as signs of the decision-maker's foreign policy incompetence. The narrowed range of acceptable peaceful solutions then leads to longer wars as the wartime bargaining process is drawn out or breaks down.

The first section of the paper discusses previous work on interstate war duration and rivalries and describes the theoretical gap between the two. The theory presented in section two attempts to fill this gap by incorporating rivalry into a model of war duration through its role in wartime bargaining processes. Sections three and four present the research design, the results of a large-n empirical analysis, and discussion of the results, and section five offers conclusions about the significance of the results for future work on rivalries and interstate war duration.

\section{PREVIOUS RESEARCH}

The literature on rivalries between states begins with the empirical observation that particular dyads are involved in a disproportionate share of international conflicts, such that their frequency of involvement is higher than would be expected if all conflicts were independent events (Goertz and Diehl 1992). Commonly defined in terms of a minimum number of disputes in a set time period between the same two actors (Gochman 
and Maoz 1984, Goertz and Diehl 1992), rivalry has been posited as a factor directly influencing war initiation (Goertz and Diehl 1992) and has been used to define a subset of cases in studies of general deterrence (Huth and Russett 1993) and the effect of changes in the distribution of power on war initiation (Geller 1993).

The intuition behind recent work on rivalry and war initiation is that past conflict shapes current and future decisions about entering interstate wars and that states "learn" from past interactions (Leng 1983, 1988; Mor and Maoz 1999). The same intuition is present in game theoretic work that focuses on factors encouraging international cooperation. When interaction occurs repeatedly, actors develop histories of behavior that are known wholly or partially by other actors in the system. Future interactions are influenced by common knowledge of previous behavior, so that states with histories of reneging on agreements are known to have such a history and are viewed as having a higher probability of reneging in the future, and states with histories of violent action are viewed as having a higher probability of being violent.

Unfortunately, the intuition developed in the literature on rivalries faces definitional, theoretical and measurement problems (Thompson 1995; Vasquez 1996). For example, within a key article by Goertz and Diehl, the measurement of rivalry is inconsistent with the stated definition, as rivalries that are expected to be linked by competitiveness (some form of issue linkage between conflicts), time, and spatial consistency are measured only in terms of time and spatial consistency (Goertz and Diehl 1992). While it is a well-considered look at an important topic, Goertz and Diehl's approach, adopted in recent work on war duration, leaves some room for improvement. The areas in which improvements might be possible are discussed in greater detail below, 
but the time period in which disputes are expected to matter is one such area. If we use Goertz and Diehl's (1992) (and Bennett and Stam's) choice of time period, then we would expect (counterintuitively) any residual rivalry between World War I combatants to have ended prior to the outbreak of World War II, and we would not expect that history to have any effect on wartime calculations.

Rivalry remains a challenging concept with broad implications for the study of interstate war and conflict, but its use thus far has been limited in application and in diversity of operationalization. In addition, the causal mechanism through which rivalry is expected to affect the nature, not just the initiation, of interstate war has received too little attention in research to date.

Following an almost completely separate path is the relatively small literature on the factors influencing the duration of interstate wars. Much of the recent work on the duration of international events has focused on the costs and benefits of involvement in those events for the rational actors assumed to be making policy decisions. Decisions to enter or exit wars, for example, are influenced by elements of those wars that affect the stakes and the costs of winning and losing, staying in the war or leaving it, etc. Factors that affect the costs of involvement or the stakes attached to continued involvement will also influence the duration of the event. Rational actors continually reassess the expected utility of continuing involvement in a given international event, and when costs outweigh benefits, they withdraw through negotiation or surrender (Bennett and Stam 1996, 240).

Early expected utility models of interstate war duration articulated this intuition. Donald Wittman (1979) provides a rational model of war termination in which actors decide to withdraw when costs outweigh benefits, concluding that a reduction in 
hostilities may prolong a war by decreasing the costs to both sides. Wittman uses Singer and Small's 1972 data to test a limited model that includes battle deaths as a measure of hostility, the number of nations involved, a dummy distinguishing interstate and extrasystemic wars, and a measure for technological change, but the OLS model used is statistically inappropriate for event duration, as war duration is positive by construction. ${ }^{2}$ In another formal discussion of war duration, Mitchell and Nicholson (1983) consider the appropriateness of the expected utility model for the case of the Boer War for the purpose of hypothesis generation rather than testing and, finding that the fit is poor, suggest adaptations to improve the fit for an individual case.

Expanding early formal work into the realm of large-n testing, Vuchinich and Teachman (1993) use part of a larger study on riots, wars, and family arguments to focus on only a few independent variables (number of nations, population ratio, and year) as coded in Small and Singer's international war data. In a hazard analysis, more appropriate to studies of the duration of events than OLS, they find statistical significance only for the scale parameter that denotes the speed and direction of change in the baseline probability that the event will end at a given moment (the hazard rate). ${ }^{3}$ Their finding that the likelihood that a war will end decreases as the war becomes longer agrees with many later studies of interstate war duration, but their inclusion of only two substantive predictors, the number of actors and the population ratio, leaves us with a model of war duration that leaves out many concepts considered important determinants of the nature of wars.

In response to this underspecified model, Bennett and Stam (1996) provide an alternative model of war duration. While the authors suggest that they draw together 
hypotheses from realpolitik and domestic factors literatures, the article focuses heavily on the role of realpolitik factors, particularly military strategy choice. Coding the pertinent variables primarily based on ex ante information, Bennett and Stam test their composite model on a data set that includes 77 wars between 1816 and 1985, finding that their model is a significant improvement over the Vuchinich and Teachman model. Table 1 describes both models.

\section{$<$ TABLE 1 HERE $>$}

While Bennett and Stam's model represents a significant improvement over the Vuchinich and Teachman model, neither model adequately incorporates rivalry. Despite the finding that much of the violent conflict between states breaks out in the context of rivalry (see Goertz and Diehl 1992), Vuchinich and Teachman do not consider the effect of rivalry at all, while Bennett and Stam apply the same basic count measure that is found in early work on rivalries such as Goertz and Diehl (1992). Their theoretical justification for including this variable is based on the findings of Goertz and Diehl on war initiation and their brief speculation that

"[As disputes] recur domestic constituencies are likely to form in opposition to the opponent (as was the case over time during the Cold War in the United States). The longer the history of conflict between the states, the easier it will be for leaders to continue to justify continued fighting to domestic audiences. Previous disputes thus may institutionalize conflict" (Bennett and Stam 1996, 243). 
However, while their intuition seems plausible, they fail to provide a full causal theory or elaborate on their supposition. Even if they were to do so, their count measure fails on a number of counts as a measure of rivalry. The count measure includes only disputes occurring in the previous ten years, ignores hostility levels of the counted disputes, and by its nature attributes equal influence to all counted disputes regardless of how early or late in the counted period. ${ }^{4}$ This measure will be discussed in the research design section, along with the improved measure to be used in this paper's test of the importance of rivalry in determining war duration.

The research discussed above focuses on the balance of costs and stakes attached to involvement in interstate war, using this balance as the theoretical basis for hypothesis formation and quantitative testing. However, this paper uses another theoretical starting point based on the work of Wagner (2000), and indirectly, Fearon (1995). Fearon (1995) focuses on war initiation rather than duration, but he introduces the ideas revised and expanded upon by Wagner (2000). The author argues that a range of possible distributions of benefits exists between the ideal positions of states in conflict over an issue. Within this larger range, there is a "bargaining range" consisting of possible distributions that are superior to going to war for both sides. Settlements that avoid war are those within the bargaining range that can be located by the two states, but rational states may still go to war if they cannot locate such a negotiated settlement. Fearon argues that these settlements may not be reached when private information about resolve or capabilities and incentives to misrepresent that information exist, when there are commitment problems, or when issues are indivisible. 
Fearon elaborates on these mechanisms for war between rational states and suggests that they explain the failure of states to reach bargained settlements better than explanations focusing on the role of anarchy, expected utility, motivations for preventive war, or rational miscalculation. While Fearon's concepts and argument here are fundamental in the bargaining literature, Wagner's (2000) revision and expansion of Fearon's work is more directly pertinent to the topic of war duration.

Wagner suggests that Fearon's understanding of the bargaining process connected to war assumes incorrectly that war represents a total breakdown of bargaining, and that instead, war initiation and war duration are tied together by an ongoing bargaining process that differs in key ways from the one described by Fearon. Private information about resolve and capabilities is not as important once fighting begins, as battles themselves reveal information about capabilities in ways that make it known to both states. Wagner's extension of Fearon's work provides the formal framework most useful for this paper because factors that make this type of bargaining breakdown more likely will also lengthen wars.

The literature on rivalries and the literature on interstate war duration both stand to benefit from the contributions of this paper. The theory laid out below draws on the work of Fearon and Wagner, providing a clear causal mechanism through which preexisting rivalries between pertinent actors affect the duration of interstate wars. This will be incorporated into a larger model of interstate war duration and tested for model improvement and significant, positive effects on war duration associated with increasingly hostile relationships.

\section{THEORY}


The theory posited here begins with Wagner's (2000) argument that the bargaining process does not stop when war breaks out. ${ }^{5}$ Wagner argues that what Clausewitz called "real wars" can be a way of revealing private information about military capabilities, providing knowledge that affects eventual negotiated outcomes. As noted above, this argument offers a dynamic alternative to the signaling processes that are the focus of Fearon's work and are assumed to stop once states begin to fight.

This approach seems especially pertinent for the research question posed here, since my focus is on the factors that influence the duration of war once war has begun rather than on factors that primarily influence war initiation. ${ }^{6}$ If the bargaining process continues once fighting has begun between states, then the question that a theory of war duration must answer is what factors can influence this wartime bargaining process in such a way that they lead to longer or shorter wars? In other words, what determines states' willingness to persevere in conflict rather than reach a negotiated settlement?

Within this theoretical framework of wartime bargaining processes between states, I argue that rivalry plays a key role in determining the duration of the interstate war. Rivalry has this effect because as information available at the time of the decision to continue fighting or to negotiate, it affects the selectorate, or group capable of removing the central decision maker from power (see Bueno de Mesquita and Siverson 1997), in such a way that the selectorate becomes less willing to accept war-ending settlements outside of an increasingly narrow range. Drawing on the idea of the bargaining range and extending it into wartime bargaining, we would expect the likelihood of a breakdown in the bargaining process to be dependent on the size of the bargaining range (or set of settlements that both sides find preferable to continued 
fighting). It follows that if rivalry makes the selectorate more demanding regarding the terms of any negotiated settlement ending the war, and the selectorate thus places constraints on the range of settlements that the central decision maker is able to accept, then the duration of war should increase in cases of higher levels of preexisting rivalry. The causal chain posited, then, is as follows.

\section{Figure 1. Causal Chain.}

Magnitude of Rivalry $\rightarrow$ Selectorate Reaction $\rightarrow$ Range of Acceptable Bargains $\rightarrow$ War Duration

In the first link of the causal chain, how does the magnitude of rivalry affect the reaction of the selectorate in warring nations? The selectorate constantly reassesses the policy performance of the central decision-maker and is capable of removing the decision maker from power in the case of perceived policy failure (Smith 1996). While domestic constituencies can be expected to pay attention to any war and hold preferences over the outcome, rivalry is expected here to increase the intensity of their preference for military victory. As a result of this preference for military victory over negotiated settlement, rivalry decreases the number of peaceful settlements that constitute foreign policy success in their assessment of the decision maker. The greater the history of past conflict, the more demanding is the selectorate regarding the terms of peaceful settlements. Recent and frequent conflicts of low intensity such as frequent but minor border disputes are expected to have this effect, as are more distant but intense conflicts such as prior involvement as opponents in a regional war. Old conflicts fade from memory, while very recent conflicts have a greater impact on current assessments. Domestic constituencies may respond by "rallying around the flag" for a short time, but this initial surge of support is generally temporary, leaving room for other pressures to 
exert their effects (Mueller 1970, 1973; Oneal and Bryan 1995; Parker 1995). While there is insufficient space to include a full case study here, the case of the Chaco War between Bolivia and Paraguay (1932-1935) lends general support to this link in the causal chain, as secondary sources identify public pressure and the fear of removal from office (after an initial surge of public support for the war) as an important factor leading to failure in early negotiations (Farcau, p.111; Rout, p. 84).

In the second link of the causal chain, how does the selectorate limit the range of acceptable negotiated settlements? Here, the selectorate is expected to restrict the freedom of the decision maker through the implicit threat of removal from office in the case of policy failure. As the level of rivalry increases, the range of settlements that are perceived as policy failures also increases. For instance, if the selectorate in an autocracy consists primarily of the military elite, then in the context of rivalry, settlements that are perceived to handicap the military's ability to rearm and redeploy quickly may be seen as unacceptable in light of a history of prior conflict, while the same bargain may seem less threatening in the context of lower or nonexistent rivalry. For democratic selectorates, the mechanism may differ but the direction of the expected effect on the size of the range of acceptable war-ending bargains is the same. While this might also apply to military elites, democratic publics can be expected to update their assessment of an opponent's "type" (aggressive or simply security-seeking) as a rivalry develops, and with each update require more from any war-ending bargain in order to see that bargain as a policy success (a deal with a security-seeking state rather than an inherently aggressive one likely to attack in the future). More generally, the selectorate is expected to be more demanding of agreements struck with serious rivals and more likely to deem such 
agreements policy failures. The direction of the effect should be the same regardless of regime type.

This understanding of the selectorate and the role of its power over the decision maker differs substantially from the "audience costs" employed by Fearon and Smith to explain why democracies are expected to be able to strike better bargains in the prewar bargaining process. In this view, the costs imposed on leaders for perceived policy failure are expected to exist primarily in democracies (through the electoral process), and the way in which these costs influence bargaining outcomes is through the increased credibility that they provide for signals sent during the prewar bargaining process. This distinguishes democracies from non-democracies because the costly nature of the signals sent by democracies that make irreversible moves in front of an empowered audience improves their ability to bargain credibly.

Without taking issue with the importance of the selectorate and democracy with respect to the onset of disputes, my focus here is on how the selectorate restricts the range of acceptable wartime bargaining outcomes. Here the need to distinguish democracies from non-democracies becomes less important because the signaling process ends once war breaks out, with battles becoming the central way in which information about resolve and capabilities is revealed. If signaling ends when war begins because information revealed from battles is clear to both sides, the audience cost based distinction between democracies and non-democracies no longer applies. Other scholars have reached similar conclusions (although by different logics) about the assumed differences between democracies and non-democracies in crisis situations. Trumbore and Boyer (2000) argue that in crisis decision making situations, the decision making process in democracies 
closely resembles the process in non-democracies, and others have argued that nondemocracies should experience some version of a two-level interaction even though it may not be embodied in an electoral process (Hagan 1995, cited in Trumbore and Boyer 2000).

In the final link of the causal chain, a narrower range of acceptable war-ending bargains leads to longer wars by Wagner's logic noted above. Simply stated, if the selectorate requires that their decision maker strike a harder bargain, the likelihood that the bargain will not be accepted increases, leading to further fighting until a victor is determined through combat or a better bargain is available.

What about other plausible causal mechanisms between rivalry and war duration? Two anonymous reviewers have suggested that states' rational expectations about future conflict might be the connection between rivalry and war duration, such that states might expect future conflict with states with whom they have had prior conflicts. With an expectation of future conflict, states might be less willing to reach negotiated settlements for fear that the results will provide an advantage to the other state in future conflicts (the expected utility for a settlement is lower). This argument is consistent with Dale Copeland's (2000) dynamic differentials theory, if we are willing to extend it beyond major wars between great powers, and notably if used alone does not require any reference to domestic politics, unlike the theory posed in this paper. ${ }^{7}$ The argument is not completely different from or incompatible with the one posed in this paper, especially when we consider elite selectorates in non-democracies, where I argue that military elites might pressure leaders to continue fighting a war with a rival for fear of a settlement weakening their ability to re-arm and deploy forces in the future. It may be the case that 
both mechanisms are at work, with leaders reacting to the possible threat posed by a rival strengthened by the benefits of a war-ending settlement as well as the pressure from domestic constituencies that is the focus of this paper. Both dynamics would lead to the same empirical expectation, that increased rivalry leads to longer wars.

Admittedly, the tests below cannot clearly distinguish between the two causal mechanisms, and unfortunately the prospects for doing so are poor. While one might suggest an interaction between democracy and rivalry as a test of the two-level theory versus the strategic expectations theory, this would equate the broad concept of domestic politics with the narrow characteristic of regime type, and the results of such a test, while of general interest, would have little to say about the utility of the causal mechanism provided here. An appropriate quantitative test would require a measure of selectorate reaction for the wars studied here, but such a measure is unavailable and perhaps unobservable considering limited cross national information on public or elite sentiments in all but the most recent wars (if it is even available in those recent cases). Several detailed, carefully chosen case studies might also be able to resolve the question, but such a study is beyond the scope of this paper. In the face of insufficient data to differentiate between the two mechanisms quantitatively and insufficient space to test it qualitatively here, the question is left for future research to answer definitively.

With the theoretical basis described in this section, the question becomes whether rivalry plays a statistically significant role in determining war duration, as determined through appropriate tests. The following section endeavors to determine whether this is the case. 


\section{RESEARCH DESIGN}

\section{Sample and Unit of Analysis.}

The data used here are Scott Bennett and Alan Stam's data from their 1996 article on the duration of interstate wars. The original data set uses wars between 1816 and 1985 as the unit of analysis, providing ex ante values for several variables described below. Where more than one actor is engaged on a side of the conflict, the values represent the dominant actor only. Each value represents information available at the time of war initiation, and there are no values included in the data that represent any changes during the war. ${ }^{8}$

\section{Operationalizing Variables}

The dependent variable in this study is the duration (in months) of the war being studied and is drawn from the Correlates of War data set with updates by Bennett and Stam. The independent variables include all of those listed in Table 1 from Bennett and Stam's model, and an additional variable that measures the magnitude of rivalry. This addition is appropriate, as it follows from the theoretical argument above. One might ask whether the count variable included in the Bennett and Stam model captures the same concept, but on closer analysis, the count variable can be shown to have several serious flaws.

The first shortcoming is the time period in which earlier disputes are counted. A simple example should suffice to demonstrate that ten years is unlikely to be a period long enough to capture fully the influence of prior interaction and conflict between actors. In the early stages of World War II, rational actors making decisions about continuing involvement in the war certainly assessed the probability of success based on 
a number of military and political factors, but in Bennett and Stam's conception of historic interaction, they would not be expected to incorporate any lessons learned from prior interaction in World War I. A domestic constituency with a memory of more than ten years could not influence their conception of stakes. Clearly, if nothing else were problematic with their understanding of rivalry, this would be sufficient to question the usefulness of the measure.

However, the question of how old conflicts must be to stop influencing current decision-making is not the only one that must be raised when considering an improved model of war duration. In addition to the time period, the nature of a count variable completely ignores important facets of rivalry, specifically the level of hostility in previous conflicts. Bennett and Stam's model implicitly assumes, counterintuitively, that 30 disputes involving very low casualties and hostility as measured in the Militarized Interstate Disputes (MID) data compiled by the Correlates of War project would have the same impact on decisions to continue fighting as 30 disputes involving heavy casualties and high levels of hostility.

Finally, Bennett and Stam's model expects all of the disputes, no matter how early or late in the ten-year period, to exert the same effect on current stakes. This failure to integrate some measure of decay of the influence of previous interaction, along with the questionable time period and the failure to distinguish between hostility levels, gears their measure for failure.

Recent work in the conflict processes literature has yielded a measure of rivalry that remedies these shortcomings, and insights from the bargaining literature can help to explain the role of rivalry in determining war duration. Crescenzi and Enterline (2001) 
create a measure of historic interaction, the Interstate Interaction Score, that incorporates the hostility level of previous disputes rather than counting a massive war of attrition and a month-long border skirmish as having the same impact on future interaction, and allows for older disputes to weigh less heavily on future interaction than recent disputes. One might describe rivalry as "bad blood," and while Bennett and Stam measure the quantity, the new measure measures not only quantity, but how recent and how "bad" it is, adding a great deal of intuitively important information to the measure. ${ }^{9}$

The formula used to create the values on this variable are independent of any particular data source, and while the values have been drawn in this case from the Militarized Interstate Disputes database, the formula could be applied to any number of data sources (Crescenzi and Enterline 2001, 416). The conflict portion of the general formula is as follows, where $i_{t}$ is rivalry level for a particular dyad at time t, event temporal distance is the time that has passed since the last event, the event history is the accumulation of occurrences of conflict and cooperation between the dyad until time $t$, the degree of conflict is self-explanatory, and the conflict temporal distance is the time that has passed since the last conflict. $i_{t-1}$ is the rivalry level in the previous time period, $a$ is the relative weight on the two factors in affecting the rate of decay, and $\beta_{1}$ is a weight on the impact of the shock on $i_{t}$ that can be changed by the researcher when there are theoretical reasons to do so (416).

$$
\begin{aligned}
& i_{t}=\left(e^{-a\left(\frac{\text { Event Temporal Distance }_{t}}{\text { Event History }_{\mathrm{t}}+1}\right)}\right) i_{t-1}-\beta_{1}\left(\frac{\text { Degree of Conflict }_{\mathrm{t}}}{\text { Conflict Temporal Distance }_{\mathrm{t}}}\right), \\
& 0 \leq a
\end{aligned}
$$

This is the general formula, which incorporates a decay process for prior levels of rivalry and a growth process based on the magnitude and timing of new conflictual events 
(417). When it is applied by Crescenzi and Enterline to the COW Militarized Interstate Disputes data, the following formula is the result:

$$
i_{t}=\left(e^{-\left(\frac{\text { PeaceYears }_{t}}{\left(\text { PrevDisp }_{t}+1\right)}\right)}\right) i_{t-1}-\left(\frac{\sum_{i}^{n} \text { HostLev }_{t i}}{\text { PeaceYears }_{t}}\right),
$$

where each element reflects the general concept in its position in the general formula above. Peace Years is the time since the last dispute, HostLev is the occurrence and severity of militarized disputes in the year t, and PrevDisp is the equivalent of Event History from the general model. Each of these is coded here based on MID data, and the results are bounded between -1 and 1 , with values from 0 to 1 indicating increasingly conflictual historic interaction. While MID data includes thousands of dyad-year observations, this paper uses only the values of the bounded interaction variable for the dyad years corresponding to the initiation years for the wars in this paper's data set, consistent with the thesis that it is the magnitude of rivalry in the period leading up to the war as ex ante information that influence the duration of war. ${ }^{10}$

The count and Crescenzi and Enterline variables are not highly correlated (0.472), and the information that each captures may be seen as one facet of rivalry. One source of unique information provided by the count variable is the inclusion of conflict involvement by all of the warring parties, rather than only the two major parties coded for the rivalry variable. Future work may attempt to combine the measures through the inclusion of values on rivalry for the non-major parties, but at present the inclusion of 
both variables is sufficient. Similarly, variables of theoretical importance that came up as insignificant in Bennett and Stam's results are retained in order to facilitate a fair comparison of overall model improvement using the new measurement of rivalry. ${ }^{11}$

The following descriptions of variables retained from Bennett and Stam's (1996) model frequently paraphrase their own descriptions, with additional comments. Strategy, while perhaps in need of reoperationalization in the future, remains a concept that is expected to play a central role in the duration of wars. Maneuver, or blitzkrieg, strategies are expected to lead to shorter wars, as in the quick campaigns of German aggression in World War II, while punishment, or guerilla, strategies are expected to draw out wars into long and intractable affairs.

The balance of capabilities is another factor that is expected to be a key influence on the duration of war, such that states facing a huge disparity of forces (at a ratio of $4: 1$, for example) are likely to have shorter conflicts due to the overwhelming advantage of one side. More balanced conflicts will be longer, by the same logic. Strategy and terrain may also interact to influence duration, such that wars in which strategies are appropriate to the terrain (maneuver to open terrain, for example) will be shorter. Total military capabilities will influence war duration such that larger total forces, depleting at rates similar to those when totals are smaller, will simply last longer before total depletion. Population, as a factor supporting military force size, is expected to have an effect similar to total military capabilities.

Military quality, or the difference in the quality (equipment, training) of the militaries involved, will also affect duration. As the difference in quality increases, the war should decrease in duration. When one side obtains a military surprise over the 
other, the war should also be shorter. Finally, the last realpolitik factors considered in this model are issue salience, such that salient issues (survival, territory, unification, reputation, and autonomy are salient issues; policy, empire, and trade are not) will increase the duration of the war, and mobilization, such that mobilization should have little effect on war duration.

Bennett and Stam posit that the key domestic political variables at work in a fully specified model of war duration are repression, such that repressive leaders will choose risky wars that are likely to end quickly, and democracy, such that domestic audiences will decrease the willingness of leaders to continue long wars. Bennett and Stam, like Fearon and Smith, connect audience costs primarily to democracies. While democracies may also have an additional restraint on involvement in long wars due to domestic audiences, this is considered to be separate from the broader effect of rivalry on all rational decision makers, be it in democracies or in non-democracies. The two variables will remain separate in the model because of this distinction.

The model also includes the number of actors involved in the war, under the assertion that in larger groups, nations will provide a sub-optimal level of war involvement to their allies, as they assume that the burden will be carried by others in the coalition. Finally, the count variable measuring rivalry remains in the model, as its removal may affect the results from incorporating the improved operationalization of "bad blood," and would constitute adjusting the model to the data supposedly being used to test hypotheses drawn from that model.

The main improvement over the best recent model of war duration made here is the incorporation of a theoretically grounded measure of rivalry into the model. This 
change, while only one step in the process of creating a more accurate and sound model of war duration, represents a substantial improvement over earlier work that either assumed that war duration is independent from histories of conflict played out in front of attentive publics or modeled the concept with problematic measures of past conflict.

\section{Methodology}

Hazard or survival analysis is the most appropriate form of estimation for models in which the duration of an event is the dependent variable. This form of estimation allows for censoring, heterogeneity, and duration dependence (Bennett 1997, 857). Hazard analysis models the hazard rate, which is the instantaneous rate at which events terminate at duration $\mathrm{t}$, given that they have survived until time $\mathrm{t}$ (Bennett and Stam 1996, 244). This model estimates the hazard rate (the rate at which wars end) as a function of our predictor variables. The Weibull distribution used here allows for estimation using predictors and allows for positive, negative, or no duration dependence. ${ }^{12}$ Positive duration dependence, posited to exist in earlier underspecified models of war duration, represents an increasing expectation of war termination as the length of the war increases.

The general form of the hazard model using a Weibull distribution is:

$$
h(t)=\lambda p(\lambda t)^{p-1}
$$

where $h(t)$ is the hazard rate at time $t, \lambda$ is a constant until covariates are introduced, and $p$ is the shape parameter that determines duration dependence (if $\mathrm{p}>1$, the hazard rate increases monotonically over time meaning that war becomes more likely to end as it grows longer; if $0<\mathrm{p}<1$, the hazard rate decreases monotonically over time meaning that war becomes institutionalized over time) (Bennett and Stam 1996, 244). Covariates are incorporated into this form as: 


$$
\lambda=e^{-\mathrm{BXi}}
$$

where BXi is the vector of covariates, which is exponentiated, with the result replacing the constant in Equation 3. Because the output is more intuitive, the coefficients shown here represent effects on survival time, rather than the actual hazard rate. This yields nearly identical coefficients of the opposite sign. For instance, a coefficient of -2.01 predicting the actual hazard rate represents a negative effect on the rate at which wars terminate, predicting longer duration. The form shown here would be approximately the same coefficient of a positive sign and would indicate a positive effect on survival time, or longer duration. In short, since coefficients here represent effects of survival times rather than the actual hazard rate, the interpretation of signs is opposite (but more intuitive). A positive coefficient generally predicts longer duration and a negative coefficient predicts shorter duration (Bennett and Stam 1996, 245).

\section{RESULTS AND DISCUSSION}

\section{$<$ TABLE 2 HERE $>$}

The results from a survival analysis of the model that includes all of Bennett and Stam's independent variables as well as the rivalry variable described above are shown in Table 2. In the case of strategy, the metrics of these dummy variables make it difficult to interpret the direction of the coefficients, but where the independent variable is continuous, positive coefficients can be interpreted as representing longer predicted war durations and negative coefficients the opposite. Bennett and Stam interpret individual parameters through the use of a hypothetical and real case, measuring prediction error. However, this is not standard practice in survival analysis, and the information gained from such a process is of questionable utility. Here, interpretation is aided by the results 
obtained when Clarify 2.0 (Tomz, Wittenberg, and King 2001) is applied to the analysis performed in this paper. The recently developed Clarify software begins with an existing regression and draws 1,000 simulated parameters from their asymptotic sampling distribution, and in the application used here, converts those simulated parameters into expected values conditional on chosen values for the explanatory variables (pp. 5-6, 15).

The most significant predictors in the old model remain highly significant in the new model, as expected. Strategy remains significant in all combinations. The balance of forces becomes slightly less significant in the new model but does not cross the 0.05 threshold, suggesting that the incorporation of rivalry does little to change the observed importance of military capabilities in determining the duration of interstate wars. Total military personnel also remains highly significant, confirming previous findings on the importance of the overall number of men at arms in a conflict. Notably, repression and democracy gain slightly in statistical significance with the inclusion of rivalry in the new model.

Democracy has a negative effect, with more democratic states expected to have shorter wars. Repression, while showing coefficients here opposite to those published in Bennett and Stam (1996), should still be considered in agreement with their results. ${ }^{13}$ Since salience and rivalry have some conceptual common ground (though their correlation here is only 0.152 ), it is interesting to note that the direction of the salience coefficient also agrees with the rivalry finding discussed below, though salience is not significant at traditional levels $(\mathrm{p}=0.122)$.

The old count and new rivalry variables are shown at the top of the table. As we can see, in the new model, the original variable is statistically insignificant and negative, 
opposite to our expectations for a measure approximating rivalry. However, the new rivalry variable created by Crescenzi and Enterline is both statistically significant and in the expected direction (positive).$^{14}$ A positive coefficient here means that we expect higher values (more hostile rivalry) on the independent variable to predict longer war durations, which is in keeping with the theory posited in this paper. ${ }^{15}$

Across the models compared here, strategy, the balance of forces, military personnel, democracy, and repression remain very significant, while parameters that were insignificant in the old model remain so in the new model. Rivalry is significant when introduced, suggesting that while realpolitik factors remain very important in determining war duration, rivalry as measured does play a significant role.

In addition, I expected the addition of an appropriately measured variable representing rivalry to improve the smaller model of war duration by a statistically significant margin. When comparing two nested models estimated through some form of maximum likelihood estimation, the likelihood ratio test is one appropriate and widely used measure of improvement between models. Other measures are available that apply to both nested and non-nested models, such as the Bayesian Information Criterion (Raftery 1995), but for ease of interpretation, the likelihood ratio test is sufficient here. The test $(\mathrm{p}=0.023)$ indicates that the addition of the new, appropriately measured variable representing rivalry does improve the model by a statistically significant margin, supporting our proposition by refuting the hypothesis that the more limited model fares better. ${ }^{16}$ Bennett and Stam employ a number of other measures in their analysis of their own results, but these measures (mean absolute error, median absolute error, mean of 
absolute error as percentage of war length) are not common among users of survival analysis and do little for our substantive interpretation of the results.

Notably, both the new and old models find that wars are not duration dependent. This means that the inclusion of the predictors used in the two models compared here seems to negate the apparent process of institutionalization in which wars become less likely to end as they become longer (Bennett and Stam 1996, 254). This finding appears to be at odds with the assertion in this paper that recent conflict intensifies preferences and lengthens wars, since the lack of duration dependence suggests that wars do not become institutionalized over time. This suggests that additional research may be useful in further exploring the patterns of institutionalization and decay in wars over time, and also for relatively rivalrous pairs versus less rivalrous pairs.

While there is no widely agreed upon method for interpreting survival analysis coefficients and the significance findings noted above should be considered the main results of this analysis, by applying the Clarify 2.0 program to the results described above, it is possible to generate expected values for war length (in months) for the minimum and maximum values of our predictor of interest, holding all other predictors at their means or modes as appropriate (continuous variables are held to their means, dummies are held to zero, and ordinal variables are held to their modes). The resulting interpretation from this procedure is that when we increase the rivalry level from its minimum to its maximum, holding all other variables at their means or modes as appropriate, expected war duration increases by approximately $341 \%$. This suggests that the effects of rivalry are not only statistically significant, but also of an impressive magnitude. 
While the interpretation facilitated by the Clarify 2.0 program is an interesting supplement, the central assertion of this paper is that rivalry has been incorrectly understood to be an unimportant predictor of war duration in the existing literature, and the finding that it is significant and improves overall model fit strongly suggests the opposite, contradicting earlier findings.

The results of this paper indicate that the presence and magnitude of rivalry does matter in determining the duration of interstate wars. While strategy, the balance of forces, and other realpolitik factors remain important, hostile rivalry between war actors prior to the war at hand can be expected to increase the duration of the war. More broadly, we can expect the historical relationship between actors to affect the nature of war between those actors, and this expectation need not be limited to histories of conflict. States with histories of cooperation and friendship may be prone to have shorter wars should they occur, and future employment of the cooperation facet of Crescenzi and Enterline's variable may yield interesting results that speak to this possibility.

This paper confirms through quantitative empirical analysis that decisions about the nature and duration of interstate war do not occur in an historical vacuum, and that while realpolitik factors and stock domestic factors are expected to be important, they are not the only factors that influence the final length of wars. Crescenzi and Enterline's approach is also supported by this study, in that their variable that performs well in models of war initiation also performs well in this model of war duration, suggesting that it applies to wartime as well as pre-war decision-making. These results also suggest that simple count measures of prior conflict are insufficient and may result in the role of prior conflict being underestimated or missed altogether when appropriate measurement shows 
that its effect is significant. The development of other new measures of rivalry such as the measure used in Rasler and Thompson (2001) may offer another avenue for future research, and the findings of this paper should be seen as supporting such work that moves beyond event count measures.

While the findings of this paper are instructive, current models of war duration are in need of further study. Future research could still greatly improve our understanding of the causes of long and short wars. For instance, a number of the predictors that are included in the old and new models of war duration here are drawn from competing theoretical approaches and little work has been done to determine how they are interconnected. Current models include few interaction effects between them, and some measures (such as democracy and repression) are highly correlated, suggesting that simplification and revision might be appropriate with further study and theoretical motivation. Additionally, more research must be done to sort out the possibly competing or possibly complimentary causal mechanisms discussed in the theory section of this paper so that we may better understand the role of domestic pressures and expectations about future conflict in wartime decision-making.

\section{CONCLUSION}

While it is useful to consider the points at which literatures intersect and overlap, and to cross-fertilize between them, the purpose of employing causal theory and empirical evidence is to improve our understanding of the world and the processes underlying seemingly unpredictable phenomena. The message of this paper is clearly that history, and rivalry in particular, plays an important role in determining the seemingly unpredictable duration of interstate wars. While future research must 
determine whether this influence occurs through leaders' responses to their expectation of future conflict or through leaders' responses to the demands of domestic constituencies awakened by a rivalrous history, wartime bargaining and decisions about involvement clearly take place in the context of the past, which is indeed "present in time future." 
TABLES

Table 1. Comparison of Models.

\begin{tabular}{|c|c|c|c|}
\hline \multicolumn{2}{|c|}{ Vuchinich and Teachman } & \multicolumn{2}{|c|}{ Bennett and Stam } \\
\hline Variable & Operationalization & Variable & Operationalization \\
\hline $\begin{array}{l}\text { Population } \\
\text { Ratio }\end{array}$ & $\begin{array}{l}\text { Ratio of larger side's } \\
\text { population to smaller } \\
\text { (COW National } \\
\text { Capabilities). }\end{array}$ & $\begin{array}{l}\text { Population } \\
\text { Ratio }\end{array}$ & $\begin{array}{l}\text { Ratio of larger side's } \\
\text { population to smaller (COW } \\
\text { National Capabilities). }\end{array}$ \\
\hline $\begin{array}{l}\text { Number } \\
\text { of States }\end{array}$ & $\begin{array}{l}\text { Number of nations } \\
\text { involved in war (COW). }\end{array}$ & $\begin{array}{l}\text { Number of } \\
\text { States }\end{array}$ & $\begin{array}{l}\text { Number of nations involved } \\
\text { in war (COW). }\end{array}$ \\
\hline $\begin{array}{l}\text { Duration } \\
\text { Parameter }\end{array}$ & $\begin{array}{l}\text { Indicator of duration } \\
\text { dependence estimated in } \\
\text { hazard analysis. }\end{array}$ & $\begin{array}{l}\text { Duration } \\
\text { Parameter }\end{array}$ & $\begin{array}{l}\text { Indicator of duration } \\
\text { dependence estimated in } \\
\text { hazard analysis. }\end{array}$ \\
\hline \multirow[t]{11}{*}{ Year } & $\begin{array}{l}\text { Year of initiation minus } \\
1816 .\end{array}$ & & \\
\hline & & $\begin{array}{l}\text { Strategy: } \\
\text { OADM }\end{array}$ & $\begin{array}{l}\text { Challenger has attrition } \\
\text { strategy, status quo has } \\
\text { maneuver strategy. Based on } \\
\text { "historical consensus." }\end{array}$ \\
\hline & & $\begin{array}{l}\text { Strategy: } \\
\text { OADA }\end{array}$ & $\begin{array}{l}\text { Challenger has attrition } \\
\text { strategy, status quo has } \\
\text { attrition strategy. }\end{array}$ \\
\hline & & $\begin{array}{l}\text { Strategy: } \\
\text { OADP }\end{array}$ & $\begin{array}{l}\text { Challenger has attrition } \\
\text { strategy, status quo has } \\
\text { punishment strategy. }\end{array}$ \\
\hline & & $\begin{array}{l}\text { Strategy: } \\
\text { OPDA }\end{array}$ & $\begin{array}{l}\text { Challenger has punishment } \\
\text { strategy, status quo has } \\
\text { attrition strategy. }\end{array}$ \\
\hline & & Terrain & $\begin{array}{l}0 \text { to } 1 \text { (open to impassable) } \\
\text { based on estimated } \\
\text { movement speeds and } \\
\text { terrain. }\end{array}$ \\
\hline & & $\begin{array}{l}\text { Terrain } \mathrm{x} \\
\text { Strategy }\end{array}$ & $\begin{array}{l}\text { Strategy dummies ranked by } \\
\text { expected duration interacted } \\
\text { with terrain value. }\end{array}$ \\
\hline & & $\begin{array}{l}\text { Balance of } \\
\text { Forces }\end{array}$ & $\begin{array}{l}\text { Ratio of larger side's total } \\
\text { capabilities to smaller (COW } \\
\text { composite capabilities). }\end{array}$ \\
\hline & & $\begin{array}{l}\text { Total Military } \\
\text { Personnel }\end{array}$ & $\begin{array}{l}\text { Total personnel of both sides, } \\
\text { in millions (COW National } \\
\text { Capabilities). }\end{array}$ \\
\hline & & $\begin{array}{l}\text { Total } \\
\text { Population }\end{array}$ & $\begin{array}{l}\text { Total population, in billions. } \\
\text { (COW National } \\
\text { Capabilities). }\end{array}$ \\
\hline & & Quality Ratio & Ratio of larger side's military \\
\hline
\end{tabular}




\begin{tabular}{|l|l|l|l|}
\hline & Surprise & $\begin{array}{l}\text { expenditures/personnel to } \\
\text { smaller. }\end{array}$ \\
\hline & $\begin{array}{l}\text { 0 (no asymmetrical surprise) } \\
\text { to 1 (large asymmetrical } \\
\text { surprise). Based on } \\
\text { secondary historical sources } \\
\text { (see Stam 1996). }\end{array}$ \\
\hline & Salience & $\begin{array}{l}\text { 0 (salient to neither side), 1 } \\
\text { (salient to one side), } \\
\text { (salient to both sides). }\end{array}$ \\
\hline & Repression & $\begin{array}{l}-5 \text { (open competition) to }-1 \\
\text { (no competition). } \\
\text { Negative signs applied to } \\
\text { original measure. Based on } \\
\text { Gurr, Jaggers, and Moore } \\
\text { (1989). }\end{array}$ \\
\hline & Democracy & $\begin{array}{l}\text { Sum of democracy scores for } \\
\text { both sides. } \\
\text { Based on Gurr, Jaggers, and } \\
\text { Moore (1989). }\end{array}$ \\
\hline & Previous & $\begin{array}{l}\text { Average number of } \\
\text { reciprocated disputes lasting } \\
\text { a minimum of 30 days in the } \\
\text { ten years before each war } \\
\text { between all pairs of states on } \\
\text { the opposing sides of the } \\
\text { war. Based on COW MID } \\
\text { data. }\end{array}$ \\
\hline & & \\
\hline
\end{tabular}

$\mathrm{O}=$ Offensive

$\mathrm{D}=$ Defensive

A =Attrition Strategy

$\mathrm{M}=$ Maneuver Strategy

$\mathrm{P}=$ Punishment Strategy 
Table 2. Survival Analysis Results

\begin{tabular}{|c|c|c|c|c|}
\hline \multirow[b]{2}{*}{ Variable } & \multicolumn{2}{|l|}{ Long } & \multicolumn{2}{|c|}{$\begin{array}{l}\text { Bennett and Stam } \\
\text { (Model 5) }{ }^{17}\end{array}$} \\
\hline & $\begin{array}{l}\text { Estimated } \\
\text { Coefficient }\end{array}$ & $\begin{array}{l}\text { Estimated } \\
\text { Standard } \\
\text { Error }\end{array}$ & $\begin{array}{l}\text { Estimated } \\
\text { Coefficient }\end{array}$ & $\begin{array}{l}\text { Estimated } \\
\text { Standard } \\
\text { Error }\end{array}$ \\
\hline Rivalry & $\begin{array}{l}1.294 * * \\
(\mathrm{p}=0.020)\end{array}$ & 0.556 & & \\
\hline Prev. Dispute Count & -0.041 & 0.063 & 0.012 & 0.060 \\
\hline Strategy OADM & $3.083 * * *$ & 0.699 & $2.927 * * *$ & 0.711 \\
\hline Strategy OADA & $3.473 * * *$ & 0.656 & $3.409 * * *$ & 0.693 \\
\hline Strategy OADP & $6.362 * * *$ & 1.699 & $6.431 * * *$ & 1.885 \\
\hline Strategy OPDA & $8.931 * * *$ & 2.719 & $8.458 * * *$ & 2.897 \\
\hline Terrain & 3.266 & 3.304 & 3.567 & 3.557 \\
\hline Terrain x Strategy & -1.325 & 0.886 & -1.414 & 0.951 \\
\hline Balance of Forces & $-3.245 * *$ & 1.266 & $-3.942 * * *$ & 1.278 \\
\hline $\begin{array}{l}\text { Total Military } \\
\text { Personnel }\end{array}$ & $0.0003 * * *$ & 0.0001 & $0.000 * * *$ & 0.000 \\
\hline Total Population & 0.000 & 0.000 & 0.000 & 0.000 \\
\hline Population Ratio & 0.009 & 0.019 & 0.006 & 0.020 \\
\hline Quality Ratio & 0.000 & 0.002 & 0.001 & 0.002 \\
\hline Surprise & -0.669 & 0.639 & -0.240 & 0.646 \\
\hline Salience & 0.418 & 0.271 & 0.386 & 0.288 \\
\hline Repression & $0.385 * * *$ & 0.146 & $0.361 * *$ & 0.161 \\
\hline Democracy & $-0.195 * * *$ & 0.061 & $-0.157 * *$ & 0.066 \\
\hline Number of States & -0.043 & 0.109 & $-0.177 *$ & 0.097 \\
\hline Duration Parameter & 0.974 & 0.092 & 0.938 & 0.089 \\
\hline
\end{tabular}

${ }^{*} \mathrm{p}<0.10 * * \mathrm{p}<0.05 * * * \mathrm{p}<0.01$

Log Likelihood $=-117.466$

Number of Wars $=73$

Number of Data Points $=73$

Likelihood Ratio Test: Prob $>$ chi2 $=0.023$
Log Likelihood $=-120.045$

Number of Wars $=73$

Number of Data Points $=73$ 


\section{REFERENCES}

Anderson, Paul A. and Timothy J. McKeown. 1987. "Changing Aspirations, Limited Attention, and War." World Politics 40 (October): 1-29.

Bennett, D. Scott. 1997. "Testing Alternative Models of Alliance Duration, 1816-1984." American Journal of Political Science 41 (July): 846-878.

Bennett, D. Scott. 1999. "Parametric Models, Duration Dependence, and Time-Varying Data Revisited.” American Journal of Political Science 43 (January): 256-270.

Bennett, D. Scott and Allan C. Stam III. 1996. "The Duration of Interstate Wars, 18161985.” American Political Science Review 90 (June): 239-257.

Bennett, D. Scott and Allan C. Stam III. 1998. "The Declining Advantages of Democracy: A Combined Model of War Outcomes and Duration." Journal of Conflict Resolution 42 (June): 344-366.

Box-Steffensmeier, Janet M. and Bradford S. Jones. 1997. "Time is of the Essence: Event History Models in Political Science." American Journal of Political Science 41 (October): 1414-1461.

Bueno De Mesquita, Bruce and Randolph M. Siverson. 1997. "Nasty or Nice? Political Systems, Endogenous Norms, and the Treatment of Adversaries.” Journal of Conflict Resolution 41 (February): 175-199.

Cioffi-Revilla, Claudio. 1991. "On the Likely Magnitude, Extent, and Duration of an Iraq-UN War.” Journal of Conflict Resolution 35 (September): 387-411.

Clodfelter, Michael D. 1992. Warfare and Armed Conflicts: A Statistical Reference to Casualty and Other Figures, 1618-1991. Jefferson, NC: McFarland and Company, Inc.

Conybeare, John A. C. 1992. "Weak Cycles, Length and Magnitude of War: Duration Dependence in International Conflict." Conflict Management and Peace Science 12 (Fall): 99-116.

Copeland, Dale C. 2000. The Origins of Major War. Ithaca, NY: Cornell University Press.

Crescenzi, Mark J.C. 2000. Exit Stage Market: Market Structure, Interstate Economic Interdependence and Conflict. Ph.D. dissertation, University of Illinois at Urbana-Champaign. 
Crescenzi, Mark J.C. and Andrew J. Enterline. 2001. "Time Remembered: A Dynamic Model of Interstate Interaction.” International Studies 45 (September): 409-431.

Diehl, Paul F. and Gary Goertz. 2000. War and Peace in International Rivalry. Ann Arbor: The University of Michigan Press.

Duke, Alan. "Doubts Plagued LBJ on Vietnam Early in the War." CNN Online. 15 February 1997. Available from http://www.cnn.com/US/9702/15/lbj.vietnam/; internet, accessed 29 November 2000.

Epstein, Joshua M. 1987. Strategy and Force Planning: The Case of the Persian Gulf. Washington, DC: Brookings Institution.

Farcau, Bruce W. 1996. The Chaco War: Bolivia and Paraguay, 1932-1935. Westport, CT: Praeger Publishers.

Fearon, James D. "Rationalist Explanations for War.” International Organization 49 (Summer): 379-414.

Garner, William R. 1966. The Chaco Dispute: A Study of Prestige Diplomacy. Washington, DC: Public Affairs Press.

Geller, Daniel S. 1993. "Power Differentials and War in Rival Dyads." International Studies Quarterly 37 (June): 173-193.

Goemans, H.E. 2000. War and Punishment: The Causes of War Termination and the First World War. Princeton: Princeton University Press.

Goertz, Gary and Paul F. Diehl. 1992. "The Empirical Importance of Enduring Rivalries.” International Interactions 18 (April-June): 151-163.

Goertz, Gary and Paul F. Diehl. 1993. "Enduring Rivalries: Theoretical Constructs and Empirical Patterns." International Studies Quarterly 37 (June): 147-171.

Goertz, Gary and Paul F. Diehl. 1995. "The Initiation and Termination of Enduring Rivalries: The Impact of Political Shocks." American Journal of Political Science 39 (February): 30-52.

Gurr, Ted Robert, Keith Jaggers, and Will H. Moore. 1989. "Polity II data set, ICPSR 9263.” Boulder, CO.

Hagan, Joe D. 1995. "Domestic Political Explanations in the Analysis of Foreign Policy." In Laura Neack, Jeanne A. K. Hey and Patrick J. Haney, eds., Foreign Policy Analysis: Continuity and Change in Its Second Generation. Englewood Cliffs, NJ: Prentice-Hall. 
Hensel, Paul R. 2001. "Evolution in Domestic Politics and the Development of Rivalry: The Bolivia-Paraguay Case." In William R. Thompson, ed., Evolutionary World Politics. New York: Routledge.

Huth, Paul and Bruce Russett. 1993. "General Deterrence Between Enduring Rivals: Testing Three Competing Models." American Political Science Review 87 (March): 61-73.

Huth, Paul, D. Scott Bennett and Christopher Gelpi. 1992. "System Uncertainty, Risk Propensity, and International Conflict Among the Great Powers." Journal of Conflict Resolution 36 (September): 478-517.

Ikle, Fred Charles. 1991. Every War Must End. New York: Columbia University Press.

King, Gary, Michael Tomz, and Jason Wittenberg. 2000. "Making the Most of Statistical Analyses: Improving Interpretation and Presentation." American Journal of Political Science 44 (April): 347-61.

Leng, Russell J. 1983. "When Will They Ever Learn? Coercive Bargaining in Recurrent Crises." Journal of Conflict Resolution 27 (September): 379-419.

Leng, Russell J. 1988. “Crisis Learning Games.” American Political Science Review 82 (March): 179-194.

Martin, Lisa L. 1992. "Institutions and Cooperation: Sanctions During the Falkland Islands Conflict." International Security 16 (Spring): 143-178.

Mitchell, C.R., and Michael Nicholson. 1983. "Rational Models and the Ending of Wars." Journal of Conflict Resolution 27 (September): 495-520.

Mor, Ben D. and Zeev Maoz. 1999. "Learning and the Evolution of Enduring International Rivalries." Conflict Management and Peace Science 17 (Spring): $1-48$.

Mueller, John E. 1970. "Presidential Popularity from Truman to Johnson.” American Political Science Review 64 (March): 18-34.

Mueller, John E. 1973. War, Presidents, and Public Opinion. New York: Wiley.

Oren, Ido. 1995. "The Subjectivity of the 'Democratic' Peace." International Security 20 (Fall): 147-184.

Parker, Suzanne L. 1995. "Toward an Understanding of 'Rally' Effects: Public Opinion in the Persian Gulf War." Public Opinion Quarterly 59 (Winter): 526-546.

Raftery, Adrian E. 1995. "Bayesian Model Selection in Sociology." Sociological 
Methodology 25: 11-163.

Rasler, Karen and William R. Thompson. 2001. "Rivalries and the Democratic Peace in the Major Power Subsystem." Journal of Peace Research 38 (November): 659683.

Rout, Leslie B., Jr. 1970. Politics of the Chaco Peace Conference 1935-1939. Austin: University of Texas Press.

Schultz, Kenneth A. 2001. "Looking for Audience Costs." Journal of Conflict Resolution 45 (February): 32-60.

Singer, J. David, Stuart Bremer, and John Stuckey. 1972. "Capability Distribution, Uncertainty, and Major Power War, 1820-1965." In Peace, War and Numbers, ed. Bruce Russett. Beverly Hills: Sage Publications.

Small, Melvin, and J. David Singer. 1982. Resort to Arms: International and Civil Wars, 1816-1980. Beverly Hills: Sage Publications.

Smith, Alastair. 1996. "Diversionary Foreign Policy in Democratic Systems." International Studies Quarterly 40 (March): 133-153.

Spiro, David E. 1994. “The Insignificance of the Liberal Peace.” International Security 19 (Fall): 50-86.

Thompson, William R. 1995. "Principal Rivalries.” Journal of Conflict Resolution 39 (June): 195-223.

Tomz, Michael, Jason Wittenberg, and Gary King. 2001. CLARIFY: Software for Interpreting and Presenting Statistical Results. Version 2.0. Cambridge, MA: Harvard University, June 1. http://gking.harvard.edu.

Trumbore, Peter F. and Mark A. Boyer. 2000. "International Crisis Decisionmaking as a Two-Level Process." Journal of Peace Research 37 (November): 679-697.

Vasquez, John A. 1996. "Distinguishing Rivals That Go to War from Those That Do Not: A Quantitative Comparative Case Study of the Two Paths to War." International Studies Quarterly 40 (December): 531-558.

Vuchinich, Samuel and Jay Teachman. 1993. "Influences on the Duration of Wars, Strikes, Riots, and Family Arguments." Journal of Conflict Resolution 37 (September): 544-568.

Wagner, R. Harrison. 2000. "Bargaining and War." American Journal of Political Science 44 (July): 469-484. 
Werner, Suzanne. 1999. "Choosing Demands Strategically: The Distribution of Power, the Distribution of Benefits, and the Risk of Conflict." Journal of Conflict Resolution 43 (December): 705-726.

Wittman, Donald. 1979. "How a War Ends: A Rational Model Approach.” Journal Of Conflict Resolution 23 (December): 743-63. 


\section{NOTES}

${ }^{1}$ The term "selectorate" has been widely used in the field of international relations (see Bueno de Mesquita and Siverson 1997 for an example) and refers here to the domestic constituency that has the power, electoral or otherwise, to remove the decision-maker involuntarily from office.

${ }^{2}$ See Bennett and Stam's reference (1996, p. 239) to a flawed OLS model by Bueno de Mesquita.

${ }^{3}$ The hazard rate and scale parameter will be discussed in the empirical section of this paper.

${ }^{4}$ See Crescenzi and Enterline (2001), e.n. 4.

${ }^{5}$ I thank Mark Crescenzi for pointing out Wagner's argument.

${ }^{6}$ The results and conclusions of this paper regarding the role of rivalry in determining war duration are of course conditional on the war already having begun.

${ }^{7}$ Thanks to an anonymous reviewer for suggesting this alternative causal mechanism.

${ }^{8}$ I use Bennett and Stam's Model 5 (data without time-varying covariates) for two main reasons. First, this model yielded their "best fit" even when compared to time-varying covariates data on the same wars and thus provides a good benchmark for comparison. Second, their key independent variables representing strategy combinations are not time-varying, and thus their extension to the time-varying covariates analysis imputes strategy combinations that may or may not have existed in the year being considered.

${ }^{9}$ The treatment given to Crescenzi and Enterline's (2001) measure here is necessarily brief. Interested readers should refer to the complete description in their article.

${ }^{10}$ While it would be appropriate and necessary to implement a one year lag if I were studying war initiation (as do Crescenzi and Enterline 2001), there is no clear reason to expect tautology as a result of not lagging the International Interaction Score in this study. The outcome being explained here is war duration, and the IIS calculations bring in no information about the duration of hostile events when creating a value for a given pair in a given year. Moreover, it can be argued that including the onset of the war whose duration is being explained is substantively important. All decisions about whether or not to continue fighting necessarily take place at some moment after the onset of the war, therefore the onset itself is ex ante information at the time of the decision. If tautology is unlikely in this case, why leave this important information out of our calculations? When states consider continuing or withdrawing from an existing conflict, it seems more realistic to assume that the selectorates do in fact take the onset of the existing conflict into account as an event that shapes their view of the rivalry relationship.

11 The results shown here reflect data that differ from the original Bennett and Stam (1996) data set regarding the number of cases included because of missing data in the rivalry measure. In four cases, data is missing from the Crescenzi and Enterline (2001) measure due to there being insufficient data in the base set needed to compile the measure. This drops the number of cases available for analysis from 77 to 73 .

${ }^{12}$ While the Weibull is a flexible and reasonable choice (as well as providing maximum comparability to Bennett and Stam's results), the Cox model is also widely used in hazard analysis. The Cox form of this analysis yields only minor changes, generally decreasing significance levels (as one would expect). These lower levels would not, however, change the substantive conclusions of the paper.

${ }^{13}$ In my initial replication of their results, I found coefficients very nearly equal to theirs, also with opposite signs. The command files for use with LIMDEP correct this problem, but the original format was left uncorrected when transferred to STATA.

${ }^{14}$ This result holds true even if the decay rate assumption is changed when creating the rivalry variable. The decay rate used in Crescenzi and Enterline (2001) and for the regression results shown here is -1 , but additional regressions using decay rates of -5 (much faster), -0.5 (slower), and -0.25 (much slower) yield 
positive estimated coefficients at the same significance level $(\mathrm{p}=0.29,0.14$, and 0.12 respectively). This indicates that the results are robust over various decay rate assumptions and that the results are not driven by my choice.

${ }^{15}$ In response to an anonymous reviewer's request, I have performed the analysis with an interaction term for rivalry and democracy. In this analysis, the rivalry variable used above retains its sign and significance level, while the interaction term is insignificant.

${ }^{16}$ The new rivalry measure remains significant at $0.05(\mathrm{p}=0.026)$ when the old count variable is dropped, and the model including the new rivalry variable remains a significant (LR test of 0.029 ) improvement over a model without either measure (in the 73-observation version presented below).

${ }^{17}$ To maximize comparability, Bennett and Stam's procedures and variables were applied to the data set used here, which includes four less observations than the set used in their 1996 article (as noted in endnote 10). In order to check that Stata 6.0 (used here) and Limdep (used by Bennett and Stam) can produce the same results using the same data and procedures, I closely replicated their results using their complete data set (converted to Stata format) and the Stata command "weibull length oadm oada oadp opda Rterrain Rterrstr bofadjbg summperB sumpopbg popratbg qualratB surpdiff salscale reprsumB demosumB adis3010 nactors". This command uses coefficients referring to survival times as the default output (rather than hazards), and STATA automatically uses the natural log of the length variable when the weibull command is used. 